\title{
Inheritance of Yield and its Components in Two Bread Wheat Crosses Under Normal and Water Stress Conditions
}

\section{Feltaous, Y.M.}

Wheat Research Department, Field Crops Research Institute, Agricultural Research Center, Giza, 12619, Egypt.

Email: feltaous80@yahoo.com

Received on: $23 / 8 / 2020$

Accepted for publication on: 30/8/2020

\begin{abstract}
:
The present investigation was conducted at Shandaweel Agricultural Research Station - Field Crops Research Institute (FCRI), Agricultural Research Center (ARC) through three successive winter seasons from 2015/16 to 2017/18. The experimental material included six populations i.e. $\mathrm{P}_{1}, \mathrm{P}_{2}, \mathrm{~F}_{1}, \mathrm{~F}_{2}, \mathrm{BC}_{1}$, and $\mathrm{BC}_{2}$ for two bread wheat crosses viz Shandaweel $1 \times$ Sids 1 and Line $1 \times$ Sids 12 . Six parameters model was applied for studying inheritance of seven agronomic traits; days to heading (DH), no. of spikes/plant (S/P), plant height (PLH), biological yield / plant (BY), grain yield/plant (GY),100-grain weight (100-KW), and no. of kernels/spike (K/S) under normal irrigation (5 irrigations) and water stress conditions (3 irrigations). The results showed significant or highly significant differences among the included materials. Mean performance of $F_{1}$ generation in cross 1 and cross 2 override mid-parents or/and best parent for most of the reviewed traits under investigation except plant height in cross 2 under stress conditions. The results of scaling tests indicated that at least one of these scales is significant and additive-dominance model is inadequate, consequently six parameters model is applicable. The results indicated that gene main effect was highly significant for all the studied traits. Additive gene effect was significant for most of the traits in combinations of the crosses and environments. The results showed that non-allelic interactions were significant or highly significant with positive sign for some traits and with negative sign for the others. The results indicated that duplicate epistasis was predominant while complementary epistasis was found only in one case. The average degree of dominance indicated presence of partial, complete, and over dominance. Broad, narrow sense heritability and genetic advance values were moderate to high. The results of the current investigation revealed that the included material can be used for producing high yielding lines under stress water conditions deploying selection in early generation for some traits and in advanced generation in the others.
\end{abstract}

Keywords: Quantitative traits, gene action, dominance, additive, epistasis.

Introduction:

Wheat is one of the most important crops across the globe since it is the major source for protein and energy for both developed and developing countries. It provides approximately $20 \%$ of the protein for more than half of the world population. The world total wheat planted area is 214.29 million hectares produced 734.05 million metric tons in 2018 (FAOSTAT 2018). In Egypt, wheat cultivated area in 2018 was 1.32 million hectares (equal to 3.20 million feddan; fed. $=2.38$ hectares $)$ producing 8.80 million tons (FAOSTAT 
2018). Wheat takes big consideration because of the gap between production and consumption which cost government a huge amount of hard currency for wheat imports. Therefore increasing wheat production both horizontally or vertically, is the key to reduce this gape and consequently save hard currency.

Under scarcity of water resources and climate change impacts, improving high yielding genotypes and tolerant to limited water resources and high temperature is a mandatory objective for breeding programs. To achieve this goal, understanding the genetic control of yield and tolerance related traits under limited water must be fully understood. Yield and tolerance to water stress associated traits are quantitative traits controlled by complex genetic basis. Dissection the genetic basis of high yield and water stress related traits pave the way for breeder to unlock the genotypes high potentiality under these conditions.

Breeding strategy mainly depends on the different gene effects i.e. dominance, additive, and noneallelic interaction. Generation mean analysis is a tool for designing the most appropriate breeding approaches to develop crop varieties with desired traits and commonly used in studying inheritance of quantitative traits. Application of generation mean analysis procedure is based on the hypothesis that the studied generations must arise from a cross involving two contrasting genotypes. This model is free from the limitations of other models and can estimate the genetic markers needed for each trait (Mather and Jinks 1971). In this way, in addition to estimates of additive and dominance gene effects, the effects of epistasis can also be estimated using the scaling test. Considerable studies in this concern were conducted by many investigators e.g. Kearsey and Pooni (1996), Farshadfar et al. (2001), Novoselovic et al. (2004), Erkul et al. (2010), Farshadfar et al. (2013), Ljubicic et al. (2016a) and Ljubicic et al. (2016b).

The six parameters technique (Mather and Jinks, 1982) was used, in this study, to evaluate wheat crosses and to estimate the components of genetic variance, gene action and generation means. With the development of the six parameters analysis as a technique for quantitative inheritance it is possible to investigate the direct genetic control of the characters in such random sample of bread wheat genotypes.

The purpose of this study is estimation the types of gene effects controlling yield and yield components in two wheat crosses in order to enable wheat breeders choosing the suitable breeding approaches.

\section{Material and methods:}

The present investigation was conducted at Shandaweel Agric. Res. Stat., Field Crops Research Institute (FCRI), Agricultural Research Center (ARC). The study was carried out during three winter growing seasons from $2015 / 2016$ to $2017 / 2018$. Two bread wheat crosses i.e. Shandaweel $1 \times$ Sids 1 and Line $1 \times$ Sids 12 were included in this study. The description of the two crosses is presented in Table 1. The hybrid seeds, for each cross separately, were produced in $2015 / 2016$ season. Some of the hybrid seeds, for each cross, were 
planted to produce $\mathrm{F}_{1}$ plants. Backcross for the first parent $\left(\mathrm{BC}_{1}\right)$ and for the second parent $\left(\mathrm{BC}_{2}\right)$ were developed by crossing the $F_{1}$ plants with each respective parents. The rest of $F_{1}$ plants were left for selfing to produce $F_{2}$ seeds. By the end of the second season, six populations were available viz $\mathrm{F}_{2}, \mathrm{BC}_{1}$, and $\mathrm{BC}_{2}$ seeds were developed this season along with $\mathrm{F}_{1}$ seeds (kept from last season) and obviously there was sufficient $\mathrm{P}_{1}$ and $\mathrm{P}_{2}$ seeds.

Table 1. Brief description, pedigree, history, and source of the four genotypes used in the present investigation.

\begin{tabular}{|c|l|l|c|c|}
\hline Cross & Genotype & \multicolumn{1}{|c|}{ Pedigree and selection history } & Origin & Description \\
\hline Cross 1 & $\begin{array}{l}\text { Shan- } \\
\text { daweel 1 }\end{array}$ & $\begin{array}{l}\text { Site / Mo / 4/ Nac / Th. Ac //3* Pvn /3/ Mirlo / Buc } \\
\text { CMSS93 B00S 67S - 72Y - 010M - 010Y - 010M - 3Y-0M- } \\
\text { 0THY - 0SH }\end{array}$ & Egypt & $\begin{array}{l}\text { High yielding } \\
\text { cultivar }\end{array}$ \\
\cline { 2 - 5 } & Sids 1 & $\begin{array}{l}\text { HD2172 / PAVON "S" // 1158.57/ MAYA74"S" } \\
\text { SD46-4SD-2SD-1SD-0SD }\end{array}$ & Egypt & $\begin{array}{l}\text { Adapted for } \\
\text { stress condi- } \\
\text { tions }\end{array}$ \\
\hline Cross 2 & Line 1 & $\begin{array}{l}\text { QUAIU/5/FRET2*2/4/SNI/TRAP\#1/3/KAUZ*2/TRAP//... } \\
\text { CMSS06 B00109S - 0Y - 099ZTM - 099NJ - 099NJ - 13WYG - } \\
\text { 0B - 0SH }\end{array}$ & $\begin{array}{c}\text { No. 25 } 25 \\
\text { IBWSN } \\
2012\end{array}$ & $\begin{array}{l}\text { High yielding } \\
\text { advanced line }\end{array}$ \\
\cline { 2 - 5 } & Sids 12 & $\begin{array}{l}\text { BUC//7C/ALD/5/MAYA74/ON//1160.147/3/BBGLL/4/HAT"S"/ } \\
\text { 6/MAYA/VUL//CMH74A.630/4*SX } \\
\text { SD7096- 4 SD- 1 SD- 1 SD- 0 SD }\end{array}$ & Egypt & $\begin{array}{l}\text { Adapted to a } \\
\text { wide range of } \\
\text { environments }\end{array}$ \\
\hline
\end{tabular}

In $2017 / 2018$ season, the six populations were grown in RCBD design with three replications under normal irrigation $(\mathrm{N})$ with five irrigations as well as water stress conditions (S) with three irrigations. Each replication consists of 12 rows with 2 $\mathrm{m}$ long separated by $40 \mathrm{~cm}$ between rows and $10 \mathrm{~cm}$ between plants. Each of $\mathrm{P}_{1}, \mathrm{P}_{2}$, and $\mathrm{F}_{1}$ were sown in one row while, $\mathrm{B}_{\mathrm{C} 1}$ and $\mathrm{Bc}_{2}$ were sown in two rows and $F_{2}$ were sown in five rows of 20 plants in each row. Data for each replication were recorded on 10 guarded plants for each $\mathrm{P}_{1}, \mathrm{P}_{2}$ and $F_{1}, 75$ plants of $F_{2}$, and 20 plants of $\mathrm{BC}_{1}$ and $\mathrm{BC}_{2}$. The studied traits included the following traits; days to heading (DH), no. of spikes/plant $(\mathrm{S} / \mathrm{P})$, plant height $(\mathrm{PLH})$ in $\mathrm{cm}$, biological yield / plant (BY) in g, grain yield/plant (GY) in g,100-grain weight $(100-\mathrm{KW})$ in $\mathrm{g}$, and no. of kernels/spike $(\mathrm{K} / \mathrm{S})$.

\section{Statistical and genetic analysis:}

Statistical as well as genetic analysis was performed using SAS v9.3 (2011) software package. Analysis of variances performed for each experiment separately. The A, B, C, and D scaling test (Mather 1949 and Hayman and Mather 1955) were used to test non-allelic interaction. Inbreeding depression (I.D \%) was estimate as the average percentage decrease of the $F_{2}$ from the $F_{1}$ according to eqation of Falconer (1989). Potence ratio (PR \%) was estimated by the formula obtained by Griffmg (1950). Stress tolerance index (STI) for grain yield was computed by the formula used by Farshadfar et al. (2001). The genetic components of variance were calculated according to Mather and Jinks (1982). Genetic advance was computed according to Johnson et al. (1955) with selection intensity of $\mathrm{K}=5 \%$; (2.06) for all 
characters. Heterosis was expressed as the deviation of $F_{1}$ generation from the mid-parents or better parent average values according to Fonseca and Patterson (1968).

Results and Discussion:

Analysis of variance, as a prerequisite for estimating generation mean analysis, is presented in Table 2. Analysis of variance showed significant or highly significant differences between environments. In the meanwhile, it showed significant or highly significant differences between populations for all the measured traits.

Table 2. Analysis of variance for $\mathrm{P1}, \mathrm{P2}, \mathrm{F} 1, \mathrm{~F} 2, \mathrm{Bc}_{1}$, and $\mathrm{Bc}_{2}$ for the two bread wheat crosses

\begin{tabular}{|c|c|c|c|c|c|c|c|c|}
\hline \multirow{2}{*}{ S.O.V } & \multicolumn{8}{|c|}{ Mean squares } \\
\hline & \multirow{2}{*}{ D.f } & D H & $\mathbf{S} / \mathbf{P}$ & PLH & $\mathbf{K} / \mathbf{S}$ & 100-KW & BY & GY \\
\hline Cross 1 & & & & & & & & \\
\hline Environments (Env) & 1 & $351.25 * *$ & $23.06 * *$ & $1212.09 * *$ & $217.61 * *$ & $3.69 * *$ & $761.76^{* *}$ & $81.99 * *$ \\
\hline Env*Rep & 2 & 0.98 & 0.31 & 0.83 & 2.77 & 0.04 & $46.78 * *$ & 6.92 \\
\hline Populations (Pop) & 5 & $4.28 *$ & $1.98 * *$ & $113.65 * *$ & $59.10 * *$ & $0.43 * *$ & $144.68 * *$ & $16.11 *$ \\
\hline Env*Pop & 5 & $10.86^{* *}$ & $1.08 *$ & $34.85 * *$ & $18.87^{\mathrm{ns}}$ & $0.01^{\mathrm{ns}}$ & $21.40 *$ & $2.20^{\mathrm{ns}}$ \\
\hline Error & 20 & 1.11 & 0.40 & 6.49 & 8.68 & 0.01 & 761.76 & 5.39 \\
\hline C.V & --- & 1.05 & 6.79 & 2.42 & 8.23 & 2.55 & 7.69 & 14.63 \\
\hline Cross 2 & & & & & & & & \\
\hline Environments & 1 & $513.55 * *$ & $25.37 * *$ & $1151.47 * *$ & $459.67 * *$ & $2.28 * *$ & $1583.11 * *$ & $233.58 * *$ \\
\hline Env*Rep & 2 & 0.29 & 0.67 & 0.85 & 18.79 & 0.062 & 19.67 & 1.12 \\
\hline Populations & 5 & $23.75 * *$ & $8.17 * *$ & $103.86^{* *}$ & $19.13 *$ & 0.061 & $396.02 * *$ & $75.90 * *$ \\
\hline Env*Pop & 5 & $3.40 *$ & $0.76^{\mathrm{ns}}$ & 10.90* & $3.434^{\mathrm{ns}}$ & $0.067^{\mathrm{ns}}$ & $31.76^{\mathrm{ns}}$ & $6.27^{\mathrm{ns}}$ \\
\hline Error & 20 & 1.25 & 0.50 & 2.94 & 6.51 & 0.03 & 12.22 & 2.95 \\
\hline C.V & --- & 1.14 & 6.97 & 1.69 & 6.95 & 3.81 & 6.70 & 9.11 \\
\hline
\end{tabular}

Where: $n s,{ }^{*}$, and ** are insignificant, significant, and highly significant, respectively. Days to heading (DH), no. of spikes/plant (S/P), Plant height (PLH), Biological yield /plant (BY), Grain yield/plant (GY), 100-grain weight (100-KW), and no. of kernels/spike (K/S).

Regarding the interaction between environments and populations, it was significant or highly significant for days to heading and plant height in both crosses, while, it was nonsignificant for no. of kernels/spike, 100-kernels weight, and grain yield in both crosses. For no. of spikes/plant and biological yield interactions were significant and insignificant in cross 1 and cross 2, respectively. These results reveal the presence of genetic variation among the included materials. The significance among the six populations made it possible to go further for generation mean analysis. Same results were obtained by Ataei et al. (2017).

\section{Performance, potence ratio, and stress tolerance index:}

Mean and stander error of the six populations $\left(\mathrm{P}_{1}, \mathrm{P}_{2}, \mathrm{~F}_{1}, \mathrm{~F}_{2}, \mathrm{BC}_{1}\right.$, and $\mathrm{BC}_{2}$ ) under normal irrigation $(\mathrm{N})$ and stress water $(\mathrm{S})$ conditions for the two crosses are presented in Table 3. Mean performance values show that $\mathrm{F}_{1}$ generation means was higher than mid-parents or best parent for days to heading, plant height, 100-kernels weight, biological yield, and grain yield under both environments in cross 1 . In the contrary, no. of kernels/spike did not reach the midparents value under both environments. But in case of no. of spikes/plant, it exceeded the midparents only under normal conditions 
but did not under stress. Regarding cross 2, performance mean of $F_{1}$ override mid-parents or high parent for days to heading, no. of kernels/spike, 100-kernels weight, biological yield, and grain yield under both environments. On the other hand, plant height did not reach the mid-parents value under both environments, the same situation for no. of spikes/plant was found but only under normal conditions. The results reveal that heterotic effect controlling the measured traits and increasing alleles are more frequent than the decreasing one, except in case of plant height and number of spikes/plant. These results are in well agreement with those obtained by Ataei et al. (2017), Abdallah et al. (2019), Koubisy (2019) and Salmi et al. (2019).

The Potence ration (PR \%) values are present in Table 3. Potence ratio was used as an indicator for determining the various degree of dominance. Degree of dominance categories were reported as follow; over dominance $(\mathrm{PR}> \pm 1)$, complete dominance $(\mathrm{PR}=+1)$, partial dominance $(-1 \leq \mathrm{PR} \leq+1)$, and absence of dominance $(\mathrm{PR}=$ zero $)$. From data presented in Table 3, both complete dominance and absence of dominance categories were not expressed in both crosses. Over dominance were found in both crosses as well. In cross 1 , days to heading $(\mathrm{N})$, plant height $(\mathrm{N}$ and S), 100-kernels weight (S), and biological yield (S) were controlled by over dominance. The same was found in cross 2; number of spikes/plant (N and $\mathrm{S}$ ), no. of kernels/spike (N and S), 100-kernels weight (S), and biological yield (S). Regarding Partial dominance, it was represented in both crosses but more frequently in cross 1 than cross 2 . In the first cross, it was reported in days to heading (S), plant height $(\mathrm{N})$, no. of spikes/plant (N and S), 100-kernels weight $(\mathrm{N})$, biological yield $(\mathrm{N})$, and grain yield ( $\mathrm{N}$ and $\mathrm{S}$ ). The scenario was different in cross 2, it was infrequently where it found only in cases i.e. days to heading ( $(\mathrm{N}$ and $\mathrm{S})$, plant height ( $\mathrm{N}$ and $\mathrm{S}$ ), and 100-kernels weight $(\mathrm{N})$. These findings are in harmony with those obtained by Soliman (2018) and Koubisy (2019).

Stress tolerance index (STI) values for grain yield (Table 3). It ranged from $77.05 \%$ (22.95\% reduction) for $\mathrm{P}_{1}$ up to $84.16 \%(15.84 \%$ reduction) for $F_{1}$ in cross 1 , while it ranged from $61.19 \%$ (38.81\% reduction) for $\mathrm{P}_{2}$ to $82.47 \%(18.53 \%$ reduction) $F_{1}$. Similar results were obtained by Ataei et al. (2017) where they found reduction in grain yield reached $40 \%$ under drought conditions compared to normal irrigation. The high stress tolerance value for $F_{1}$ in both crosses indicates the effectiveness of selection in segregation generation under water stress condition. These findings are in accordance with those obtained by Said (2014) and Ljubicic et al. (2016b). 
Doi: 10.21608/ajas.2020.115959

Feltaous, Y.M., 2020

http://ajas.journals.ekb.eg/ 


\section{Adequacy of Additive-Dominance Model:}

The scaling test i.e. A, B, C, and $\mathrm{D}$ were performed to determine the efficacy of additive-dominance model for the inheritance of the studied traits. The significance of one or more of these scales indicates that additive-dominance model is inadequate for describing the inheritance of the studied trait. Results of the scaling test are presented in Table 4 for the two crosses under normal irrigation and water stress conditions.

Table 4. Scaling test parameters A, B, C and D scales for all studied traits under normal (N) and water stress (S) conditions for the two bread wheat crosses

\begin{tabular}{|c|c|c|c|c|c|}
\hline \multirow{2}{*}{ Cross } & \multirow{2}{*}{ Treatment } & \multicolumn{4}{|c|}{ Scaling test } \\
\hline & & $\mathbf{A}$ & B & $\mathbf{C}$ & D \\
\hline \multicolumn{6}{|c|}{ Days to heading } \\
\hline \multirow{2}{*}{ Cross 1} & $\mathbf{N}$ & $2.57 * * \pm 0.86$ & $-1.00 \pm 0.91$ & $0.75 \pm 1.14$ & $-0.41 \pm 0.73$ \\
\hline & $\mathbf{S}$ & $-5.03 * * \pm 0.67$ & $9.03 * * \pm 0.76$ & $-1.56 \pm 1.00$ & $-2.78 * * \pm 0.52$ \\
\hline \multirow{2}{*}{ Cross 2} & $\mathbf{N}$ & $-0.90 \pm 1.01$ & $-1.13 \pm 1.01$ & $1.27 \pm 1.38$ & $1.65 * \pm 0.83$ \\
\hline & $\mathbf{S}$ & $0.60 \pm 0.95$ & $1.60 \pm 1.09$ & $11.87^{* *} \pm 1.42$ & $4.83^{* *} \pm 0.86$ \\
\hline \multicolumn{6}{|c|}{ Plant height } \\
\hline \multirow{2}{*}{ Cross 1} & $\mathbf{N}$ & $-3.13 \pm 1.67$ & $1.10 \pm 1.52$ & $13.32 * * \pm 2.21$ & $7.68 * * \pm 1.30$ \\
\hline & $\mathbf{S}$ & $-16.07 * * \pm 1.89$ & $-4.43 * \pm 1.91$ & $-18.37 * * \pm 2.57$ & $1.07 \pm 1.44$ \\
\hline \multirow{2}{*}{ Cross 2} & $\mathbf{N}$ & $6.97 * * \pm 2.16$ & $21.83 * * \pm 2.04$ & $27.85 * * \pm 2.93$ & $-0.48 \pm 1.67$ \\
\hline & $\mathbf{S}$ & $4.63 * * \pm 2.42$ & $11.90 * * \pm 2.21$ & $35.60 * * \pm 3.38$ & $9.53 * * \pm 1.88$ \\
\hline \multicolumn{6}{|c|}{ No. of spikes/plant } \\
\hline \multirow{2}{*}{ Cross 1} & $\mathbf{N}$ & $-1.37 \pm 0.72$ & $-2.67 * * \pm 0.75$ & $-0.58 \pm 1.06$ & $1.72 * * \pm 0.55$ \\
\hline & $\mathbf{S}$ & $-1.60 \pm 0.84$ & $0.30 \pm 0.82$ & $-2.41 * \pm 1.22$ & $-0.55 \pm 0.71$ \\
\hline \multirow[b]{2}{*}{ Cross 2} & $\mathbf{N}$ & $6.63 * * \pm 1.27$ & $3.70 * * \pm 1.18$ & $14.95 * * \pm 1.67$ & $2.31 * \pm 0.96$ \\
\hline & $\mathbf{S}$ & $-0.13 \pm 1.28$ & $4.73 * * \pm 1.32$ & $8.68 * * \pm 1.82$ & $2.04 * \pm 0.97$ \\
\hline \multicolumn{6}{|c|}{ No. of kernels/spike } \\
\hline \multirow{2}{*}{ Cross 1} & $\mathbf{N}$ & $-7.74 * * \pm 1.93$ & $-0.36 \pm 2.23$ & $9.14 * * \pm 2.92$ & $8.62 * * \pm 1.58$ \\
\hline & $\mathbf{S}$ & $-5.68 \pm 3.08$ & $16.85 * * \pm 2.68$ & $28.35^{* * \pm 4.16}$ & $8.59 * * \pm 2.13$ \\
\hline \multirow{2}{*}{ Cross 2} & $\mathbf{N}$ & $4.32 \pm 3.60$ & $-1.46 \pm 3.38$ & $13.67 * * \pm 4.37$ & $5.40 \pm 2.94$ \\
\hline & $\mathbf{S}$ & $-0.82 \pm 4.13$ & $3.15^{*} \pm 1.58$ & $4.56 \pm 5.64$ & $1.11 \pm 3.22$ \\
\hline \multicolumn{6}{|c|}{ 100-kernel weight } \\
\hline \multirow{2}{*}{ Cross 1} & $\mathbf{N}$ & $-0.32 * * \pm 0.08$ & $-0.59 * * \pm 0.12$ & $-1.48^{* *} \pm 0.14$ & $-0.28 * * \pm 0.08$ \\
\hline & $\mathbf{S}$ & $-0.55^{* *} \pm 0.18$ & $-0.30 \pm 0.20$ & $-1.43 * * \pm 0.29$ & $-0.28 * \pm 0.14$ \\
\hline \multirow{2}{*}{ Cross 2} & $\mathbf{N}$ & $-0.33 \pm 0.20$ & $0.65 * * \pm 0.20$ & $-0.85 * * \pm 0.27$ & $-0.30 * \pm 0.15$ \\
\hline & $\mathbf{S}$ & $-0.13 \pm 0.21$ & $-0.02 \pm 0.19$ & $-0.60 * \pm 0.29$ & $-0.01 \pm 0.16$ \\
\hline \multicolumn{6}{|c|}{ Biological yield/plant } \\
\hline \multirow{2}{*}{ Cross 1} & $\mathbf{N}$ & $1.78 \pm 3.25$ & $14.52 * * \pm 3.05$ & $38.83 * * \pm 4.53$ & $11.27 * * \pm 2.69$ \\
\hline & $\mathbf{S}$ & $-11.80 * * \pm 4.47$ & $24.00 \pm 4.18$ & $20.13 * * \pm 5.88$ & $3.96 \pm 3.23$ \\
\hline \multirow{2}{*}{ Cross 2} & $\mathbf{N}$ & $-9.23 * \pm 3.88$ & $8.00 \pm 4.15$ & $49.57 * * \pm 5.75$ & $25.40^{* *} \pm 3.33$ \\
\hline & $\mathbf{S}$ & $-0.67 \pm 3.44$ & $15.37 * * \pm 3.42$ & $66.39 * * \pm 4.53$ & $25.84 * * \pm 2.93$ \\
\hline \multicolumn{6}{|c|}{ Grain yield/plant } \\
\hline \multirow{2}{*}{ Cross 1} & $\mathbf{N}$ & $-0.32 \pm 1.52$ & $-4.89^{* *} \pm 1.74$ & $12.31 * * \pm 2.34$ & $8.76 * * \pm 1.29$ \\
\hline & $\mathbf{S}$ & $-1.24 \pm 1.14$ & $-1.14 \pm 2.20$ & $6.25^{*} \pm 3.14$ & $4.32 * * \pm 1.56$ \\
\hline \multirow{2}{*}{ Cross 2} & $\mathbf{N}$ & $4.58 \pm 2.74$ & $9.08 * * \pm 2.47$ & $20.73 * * \pm 3.65$ & $3.53 \pm 2.05$ \\
\hline & $\mathbf{S}$ & $7.09 * * \pm 2.3999$ & $14.63 * * \pm 2.53$ & $10.27 * * \pm 3.28$ & $-5.73 * * \pm 2.02$ \\
\hline
\end{tabular}

Where: $* \& * *$ Significant and high Significant at $0.05 \& 0.01$ level of probability, respectively.

The results showed that at least one of the four scales is significant for all the studied traits, revealing the presence of none-allelic interaction or epistasis. In this case, the type of gene action can be well explained using six parameters model or digenic model. The six parameters i.e. mean 
$(\mathrm{m})$, additive (d), dominance (h), additive $\times$ additive (i), additive $\times$ dominance $(j)$, and dominance $\times$ dominance (l) effects were estimated to give clear vision for the type of gene effects which control the studied traits. These findings are in line with those reported by Ataei et al. (2017), Soliman (2018), Abdallah et al. (2019), and Koubisy (2019).

\section{Type of gene action:}

The results of six parameters model for all the studied traits in the two crosses under normal and stress conditions are present in Table 5. The estimated values for the six parameters showed that gene main effect (m) was highly significant for all measured traits. These findings indicate that the reviewed traits are quantitatively inherited and show the important of non-allelic interactions. These results are in harmony with earlier results reported by Patel et al. (2018) and Salmi et al. (2019).

Additive effect (d) was significant (Table 5) for days to heading, 100-kernels weight, and biological yield under both environments and in both crosses. Moreover, it was significant for plant height, no. of spikes/plant, and no. of kernels/spike under both environments in cross 1 and the same was found only under normal conditions in cross 2 . These results reveal that additive gene effect is important in selection for these traits in advanced generations. Similar results were obtained by Ataei et al. (2017), Patel et al. (2018), Mahpara et al. (2018), and Soliman (2018).

Dominance effect (h) was found significant and negative (Table 5) for days to heading in cross 2 under stress conditions; plant height under normal conditions in cross 1 and stress conditions in cross 2; no. of spikes/plant under normal conditions in both crosses; no. of kernels/spike under both environments in cross 1 ; biological yield under normal conditions in cross 1 and both environments in cross 2; grain yield under both environments in cross 1. Significant and positive dominance effect was found for days to heading under stress conditions in cross 1; plant height under normal in cross 1 and stress conditions in cross 2; 100kernels weight under both environments in cross 1 and normal in cross 2 ; grain yield under stress conditions in cross 2 . The present results indicate that both additive and dominance have important contribution in inheritance of the measured traits, suggesting that selection for desirable traits might be effective in early generations. These results are in agreement with those obtained by Ljubicic et al. (2016b) and Koubisy (2019).

Additive $\mathrm{x}$ additive interaction (i) was found significant with positive values (Table 5) in days to heading under stress conditions in cross 1 and both environments in cross $2 ; 100$ kernels weight under both environments in cross 1 and normal conditions in cross 2; grain yield under stress conditions in cross 2. A negative Significance was found in days to heading under stress conditions in cross 2; plant height under normal conditions in cross 1 and stress conditions cross 2; no. of spikes/plant under normal conditions in cross 1 and both environments in cross 2; no. of kernels/spike under both environments in cross 1 and normal in cross 
2; biological yield under normal conditions in cross 1 and both environments in cross 2; grain yield under both environment in cross 1 . The findings are in agreement with previous results obtained by Koubisy (2019) and Raikwar (2019).

Additive $\mathrm{x}$ dominance interaction (j) was found significant and negative (Table 5) in days to heading under stress conditions in cross 1 ; plant height under both environments in both crosses; no. of spikes/plant under stress conditions in cross 2; no. of kernels/spike under both environments in cross 1 and stress conditions in cross 2; 100-kernels weight under normal conditions in cross 2; biological yield under normal conditions in cross 1 and both environments in cross 2; grain yield under stress conditions in cross 2 . The positive significance was found in days to heading under normal conditions in cross 1; 100-kernels weight under normal conditions in cross 1; biological yield under stress conditions in cross 1; grain yield under normal conditions in cross 1. As additive $\mathrm{x}$ dominance interaction tends to segregate in the later generations it is preferred to delay selection to later segregations. These results are in harmony with Patel et al. (2018), Soliman (2018) and Koubisy (2019).

The present results reveal that non-allelic interactions i.e. additive $\mathrm{x}$ additive, additive $\mathrm{x}$ dominance, and dominance $\mathrm{x}$ dominance are important in determining the inheritance of all studied traits. Similar results were obtained by Ataei et al. (2017), where they reported that all non-allelic interactions are important factors in controlling the expression of plant height, 100-grain weight, and grain yield/plant.

Dominance $\mathrm{x}$ dominance interaction (1) was found significant or highly significant with negative values (Table 5) in days to heading under stress conditions in cross 1; plant height under normal conditions cross 1; 100-kernels weight under stress conditions in cross 2; grain yield under both environments in cross 2. Moreover, negative significance was found in days to heading under stress conditions in cross 2; plant height under both environments in cross 1 ; no. of spikes/plant under normal conditions in cross $1 ; 100$-kernels weight under normal conditions in cross 2 ; biological yield under both environments in cross 2; grain yield under normal conditions in cross 1 .

The type of epistasis can be determined only when dominance (h) and dominance $x$ dominance (1) gene effects were significant consequently type of epistasis can be determined as concluded by Kearsey and Pooni (1996). When these effects have the same sign, epistasis is of complementary type. The duplicate epistasis determined when the sign was different. The results, present in Table 5, showed the majority of the studied traits were controlled by duplicate epistasis. The complementary epistasis was observed only in plant height under stress conditions in cross 1 . 
Doi: 10.21608/ajas.2020.115959

Feltaous, Y.M., 2020

http://ajas.journals.ekb.eg/ 
While, the duplicate epistasis was found in days to heading under stress conditions in both crosses; plant height under normal conditions in cross 1 ; no. of spikes/plant under normal conditions in cross 1 ; no. of kernels/spike under normal conditions in cross $1 ; 100$-kernels weight under normal conditions in cross 2 ; biological yield under both environments in cross 2; grain yield under normal conditions in cross 1 and normal conditions in cross 2 . The presence of duplicate dominant epistasis in the expression of a trait would limit the range of variability (Kearsey and Pooni 1996). This type of epistasis limits the efficacy of selection in early generations therefore; delaying the selection to advanced generations will be a good decision to exploit the transgressive segregations. Various investigators stated similar results reported by Ljubicic et al. (2016b) and Abdallah et al. (2019), Raikwar (2019) and Salmi et al. (2019).

\section{Components of genetic variance:}

The additive genetic variance (D), (Table 6), predominantly was controlling days to heading under stress conditions in cross 1 , both environments in cross 2; plant height under both environments in cross 1 , normal conditions in cross 2; no. of spikes/plant under both environments in both crosses; no. of kernels/spike under normal conditions in cross 1 , both environments in cross 2 ; 100kernels weight under normal conditions in cross 1 , both environments in cross 2; biological yield under both environments in both crosses; grain yield under both environments in cross 1, normal in cross 2 . On the other side, dominance genetic vari- ance $(\mathrm{H})$ was controlling some cases i.e. days to heading; no. of kernels/spike and 100-kernels weight under stress conditions in cross 1 ; plant height under stress conditions in cross 2 . In case of grain yield under stress conditions in cross 2 , it was controlled equally by additive and dominance variances.

The average degree of dominance $\left(H / D^{1 / 2}\right)$, present in Table 6, ranged from $0.29-1.45$. Majority of the traits have values less than unity (0.29 - 0.98) while three cases have values greater than unity $(1.02-$ 1.45 ) but only two cases have values equal to unity. Most of the traits have values ranged from 0.29 in case of grain yield under stress conditions in cross 1 up to 0.98 for plant height under stress conditions in cross 1 . The values higher than one are 100kernels weight under normal conditions in cross 2, no. of kernels/spike under stress conditions in cross 1 , and days to heading under normal conditions in cross 1 with values 1.02, 1.11 , and 1.45 , respectively.

A separate division with values equal to unity consist of biological yield and grain yield under stress conditions in cross 2 . The above findings reveal that additive effects $\left(H / D^{1 / 2}<\right.$ 1) were more important, in majority of the traits, than dominance effects $\left(H / D^{1 / 2} \geq 1\right)$. Similar results were reported by Ataei et al. (2017), Soliman (2018) and Koubisy (2019).

\section{Heritability and genetic advance:}

Estimating heritability, either in broad sense or in narrow sense, enable plant breeders to choose the right breeding strategy. The broad sense heritability determines the heritable portion of the total variation; while 
the narrow sense heritability determines the portion of additive effect. The heritability categorised into three groups; high $(\geq 60)$, moderate (30 $60)$, and low heritability $(0-30)$ as concluded by Robinson et al. (1949). The present results (Table 6) indicate that the broad sense heritability falls between moderate to high for most of the studied traits.

The broad sense heritability, in cross 1, ranged from 43.30 for grain yield under stress conditions up to 84.42 for biological yield under normal conditions. Moreover, it ranged in cross 2 from 56.94 for 100-kernels weight under normal irrigation conditions up to 86.11 for biological yield under stress conditions. The present results revealed that high portion of the phenotypic variation can be attributed to the genetic variation. On the other side, the narrow sense heritability in cross 1 ranged from 39.00 for days to heading up to 76.92 for number of spikes/plant under stress conditions. In the meantime, it ranged in cross 2 from 37.5 for 100 kernels weight under normal irrigation up to 75.94 for biological yield under normal conditions. The values of narrow sense heritability implies that the additive effect have higher role than dominance effect in controlling the above mentioned studied traits. The present results indicate that selection process will be effective, which will result in higher response. These results are supported by those obtained previously by Farshadfar et al. (2013), Abd El-Hamid and Ghareeb (2018) and Koubisy (2019).

Genetic advance (GS \%) break down into three groups Johnson et al. (1955) i.e. low (less than 10\%), moderate (between $10 \%$ and $20 \%$ ), and high (more than 20\%). The present results in Table 6 showed that genetic advance values were high for all the reviewed traits except few cases. Days to heading in both crosses under both environments belonged to moderate category, while the low category included plant height in cross 2 under stress conditions and 100kernels weight in both crosses under normal conditions. The high genetic advance values indicate that the direct selection is effective, while the low values reveal that indirect selection can be applied for these traits with correlated high heritability traits. These results are with accordance with those reported previously by Farshadfar et al. (2013), Said (2014), Ninghot et al. (2016).

\section{Heterosis and inbreeding depres- sion:}

The $\mathrm{F}_{2}$ deviation performance of $\mathrm{F}_{1}$ generation performance as percentage value refers to inbreeding depression. Inbreeding depression results are due to fixation of unfavourable recessive genes in F2. In the most of traits negative inbreeding depression is desirable except some cases e.g. days to heading. 
The results of inbreeding depression are presented in Table 6 showed negative significant or highly significant depression for days to heading in cross 2 under stress conditions, plant height in cross 2 under both environments, number of spikes/plant in cross 1 under normal conditions, no. of kernels/spike in cross 1 under both environments, no. of kernels/spike in cross 2 under normal conditions, biological yield in cross 1 under normal conditions, biological yield in both crosses under both environments, Grain yield in cross 1 under both environments, and grain yield in cross 2 under normal conditions. These results supported by results stated by Kumar et al. (2017) and Kumar et al. (2018). In the contrast, significant or highly significant positive inbreeding depression was exhibited in plant height in cross 1 under stress conditions, no. of spikes/plant in cross 1 under stress conditions, 100-kernels weight in both crosses under both environments, and grain yield in cross 2 under stress conditions, similar results was reported by Jaiswal et al. (2018).

Heterosis calculated over midparents and best parent as a percent for all the studied traits (Table 6). In contrast of inbreeding depression, in heterosis the unfavourable recessive genes of one line or parent are masked by favourable dominant genes of other parent. Positive heterosis is preferable for most of traits except for few traits as in case of days to heading, where negative heterosis is preferable. Positive highly significant heterosis over mid-parents and best parent exhibited for Plant height in cross 1 under both condi- tions, no. of spike/plant in cross 2 under stress conditions, no. of kernels/spike in cross 2 under stress conditions, 100-kernels weight under stress conditions in both crosses, biological yield in cross 2 under stress conditions, grain yield in cross 1 under stress conditions, and grain yield in cross 2 under both environments. Positive significant or highly significant heterosis only over mid-parents was found for plant height as well as for no. of kernels/spike in cross 2 under normal conditions, 100-kernels weight in cross 1 under normal conditions, and biological yield in both crosses under normal conditions. In the other hand, positive significant or highly significant heterosis over the best parent was found for days to heading in cross 1 under normal conditions, in cross 2 under stress conditions, and grain yield in cross 1 under normal conditions. These results exhibit the important of inbreeding depression and heterosis jointly in positive selection process. These results are in well agreement with those obtained by Kumar et al. (2017), Jaiswal et al. (2018) and Kumar et al. (2018).

\section{References:}

Abd El-Hamid, E.A.M. and Z.E. Ghareeb (2018). Generation mean analysis for estimating some genetic parameters in four bread wheat crosses. Proceeding of the Seventh Field Crops Conference, Giza, Egypt, $18^{\text {th }}-19^{\text {th }}$ Dec. 2018, p 17-29.

Abdallah, E., A.H. Salem, M.M.A. Ali and K.Y. Kamal (2019). Genetic analysis for earliness and grain yield of bread wheat (Triticum aestivum L.). Zagazig J. Agric. Res. 46 (6): 1769-1784. 
Ataei, R., M. Gholamhoseini and M. Kamalizadeh (2017). Genetic analysis for quantitative traits in bread wheat exposed to irrigated and drought stress conditions. FYTON 86: 228-235.

Erkul, A., A. Unay and C. Konak (2010). Inheritance of yield and yield components in a bread wheat (Triticum aestivum L.) Cross. Turkish Journal of Field Crops 15(2): 137-140.

Falconer, D.S. (1989). Introduction to quantitative genetics $3^{\text {rd }}$ (ed.) Longman Scientifical Techniqual.UK.

FAOSTAT

(2018).

Http://Www.Fao.Org/Faostat/En/\# Data/Qc.

Farshadfar, E., F. Rafiee, H. Hasheminasab (2013). Evaluation of genetic parameters of agronomic and morpho-physiological indicators of drought tolerance in bread wheat (Triticum aestivum L.) using diallel mating design. A. J. C. S. 7(2): 268-275.

Farshadfar, E., M. Ghanadha, M. Zahravi and J. Sutka (2001). Generation mean analysis of drought tolerance in wheat (Triticum aestivum L.). Acta Agron. Hung. 49 (1): 5966.

Fonseca, S and F.L. Patterson (1968). Hybrid vigour in a seven parents diallel cross in common winter wheat (Triticum aestivum L.). Crop Science 8:85-88.

Griffing, J.B. (1950). Analysis of quantitative gene action by constant parent regression and related techniques. Genetics 35: 303-312

Hayman, B. I. and K. Mather (1955). The description of gene interaction in continuous variation. Biometrics 11:69-82.

Jaiswal, R., S.C. Gaur and S. K. Jaiswal (2018). Heterosis and inbreeding depression for grain yield and yield component traits in bread wheat (Triticum aestivum L.). Journal of Pharmacognosy and Phytochemistry 7(2): 3586-3594.

Johnson, H.W., H.F. Robinson and R.E. Comstock (1955). Estimates of genetic and environmental variability in soybean. Agron. J. 47 (7): 314 318.

Kearsey, M.J. and H.S. Pooni (1996). The genetical analysis of quantitative traits. Chapman and Hall, London. 396 p.

Koubisy, Y.S.I. (2019). Generation mean analysis in two bread wheat crosses under heat stress conditions. Egypt. J. Agric. Res. 97 (2): 589-607.

Kumar, A., A.K. Razdan, V. Sharma, N. Kumar and D. Kumar (2018). Study of heterosis and inbreeding depression for economic and biochemical traits in bread wheat (Triticum aestivum L.). J. of Pharmacognosy and Phytochemistry 7(4): 558-564.

Kumar, J., A. Kumar, M. Kumar, S.K. Singh, L. Singh and G.P. Singh (2017). Heterosis and inbreeding depression in relation to heterotic parameters in bread wheat (Triticum aestivum L.) under late sown condition. Journal of Wheat Research. 9: 32-41.

Ljubicic, N., S. Petrovic, M. Dimitrijevic and N. Hristov (2016a). Genetic analysis of some important quantitative traits in bread wheat (Triticum aestivum L.). Ekin Jornal 2(2): 47-53.

Ljubicic, N., S. Petrovic, M. Dimitrijevic and N. Hristov (2016b). Gene actions involved in the inheritance of yield related traits in bread wheat (Triticum aestivum L.). Emirates Journal of Food and Agriculture 28(7): 477-484.

Mahpara S., S. T. Hussain, J. Iqbal, I. R. Noorka and S. Salman (2018). 
Analysis of generation means for some metric plant traits in two wheat (Triticum aestivum L.) hybrids. Pure Appl. Biol. 7(1): 93102.

Mather, K. (1949). Biometrical Genetics. The Study of Continuous Variation. Methuen And Co. Ltd.; London.

Mather, K. and J.L. Jinks (1971). Biometrical Genetics $2^{\text {nd }}$ edition. Chapman and Hall, London.

Mather, K. and J.L. Jinks (1982). Biometrical Genetics. The study of continuous variation Chapman and Hall, London. P 396.

Ninghot, C.J., M.V. Boratkar, S. B. Thawari and N.R. Potdukhe (2016). Generation mean analysis for yield and yield components in wheat (Triticum aestivum L.). International Journal of Genetics 8(4): 204-206.

Novoselovic, D., Marijana Baric, G. Drezner, J. Gunjaca and A. Lalic (2004). Quantitative inheritance of some wheat plant traits. Genetics and Molecular Biology 27(1): 9298.

Patel, H.N., D. Abhishek, A. Shrivastava and S.R. Patel (2018). Genetic analysis for heterotic traits in bread wheat (Triticum aestivum L.) using six parameters model. Int. J. Curr. Microbiol. App. Sci 7(6): 239-249.

Raikwar, R.S. (2019). Genetic architecture of yield and quality traits in wheat (Triticum aestivum L.). Indian J. Genet. 79(1): 100-103.

Robinson, H.F., R.E. Comstock and P.H. Harve (1949). Estimates of heritability and the degree of dominance in corn. Agron. J. 41 (8): 352-359.

Said, A.A. (2014). Generation mean analysis in wheat (Triticum aestivum L.) under drought stress conditions. Annals of Agricultural Science 59(2): 177-184.

Salmi, M., A. Benmahammed, L. Benderradji, Z.E.A. Fellahi, H. Bouzerzour, A. Oulmi, A. Bendelkacem (2019). Generation means analysis of physiological and agronomical targeted traits in durum wheat (Triticum durum Desf.) cross. Rev. Fac. Nac. Agron. Medellín 72(3): 8971-8981.

SAS, v9.3 (2011). SAS Institute, Inc., Cary, NC, USA 2011.

Soliman, G.M.M. (2018). Genetical analysis for yield and yield component in durum wheat under different sowing dates. Proceeding of the Seventh Field Crops Conference, Giza, Egypt, $18^{\text {th }}-19^{\text {th }}$ Dec. 2018, p 133-148. 
وراثة المحصول ومكوناته فى هجينين من قـح الخبز تحت ظروف الرى العادي والاجهاد المائى يوسف محسن فلتاؤوس

قسم بحوث القمح - معهد بحوث الدحاصيل الحقليه - مركز البحوث الزراعيه

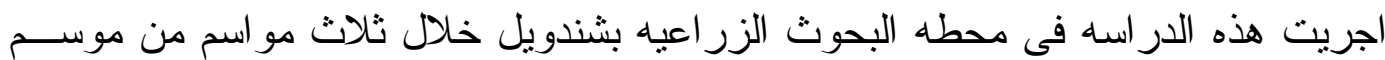

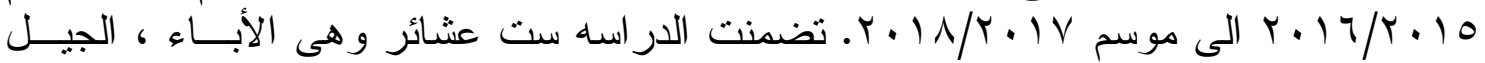

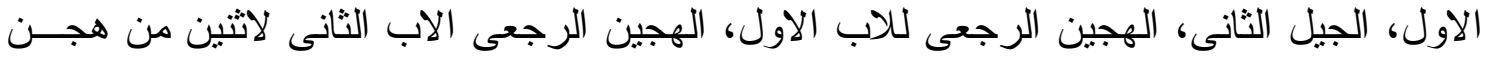

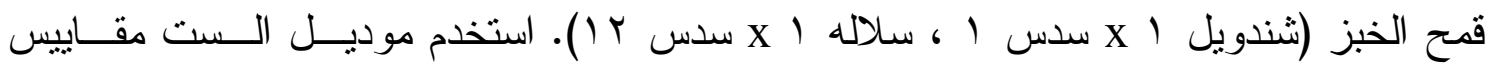

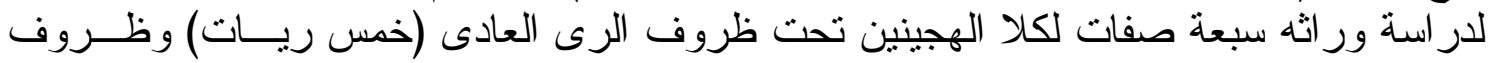

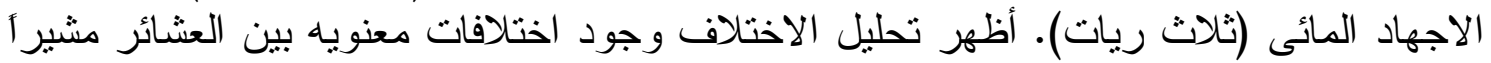

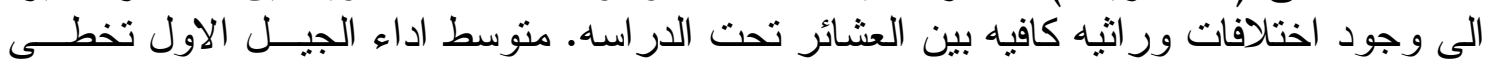

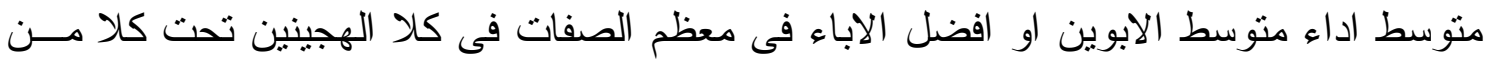

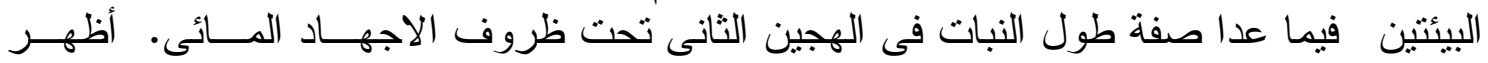

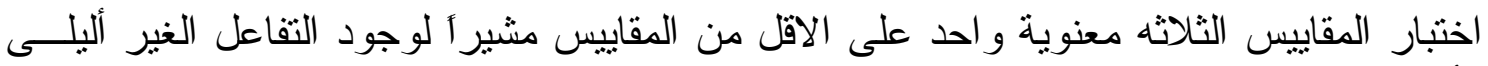

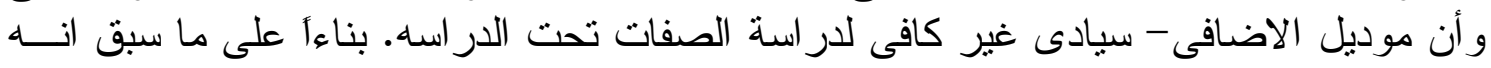

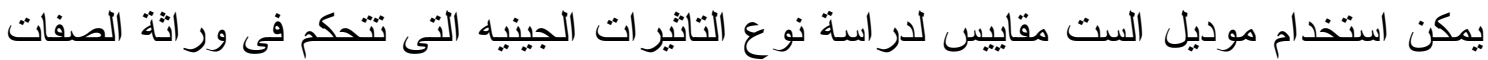

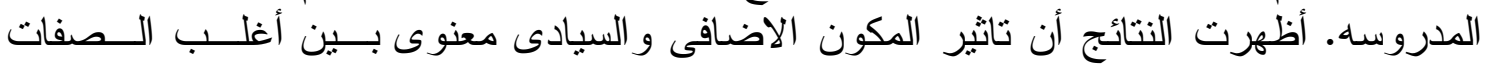

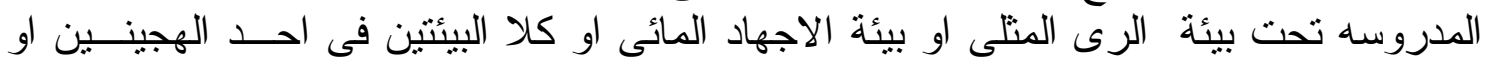

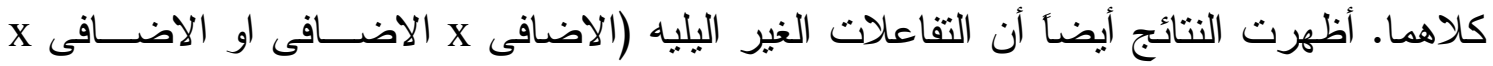

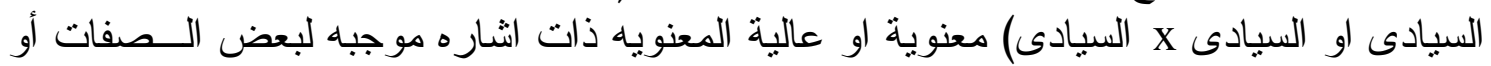

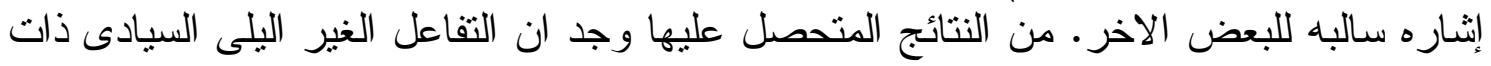

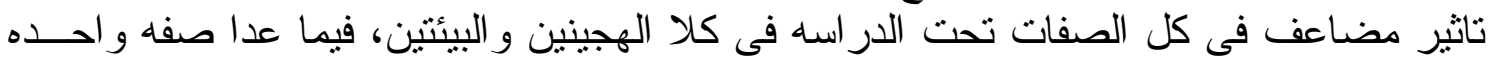

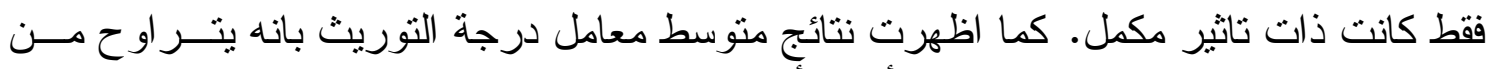

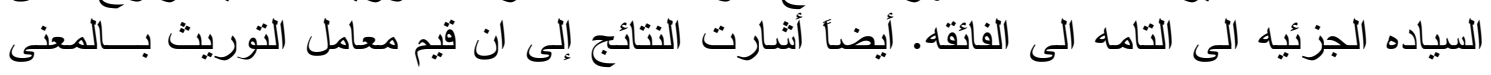

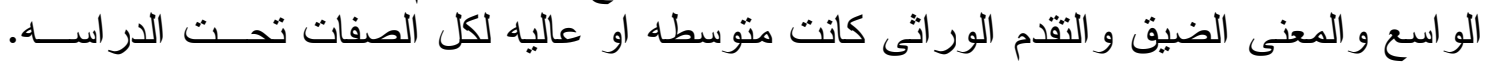

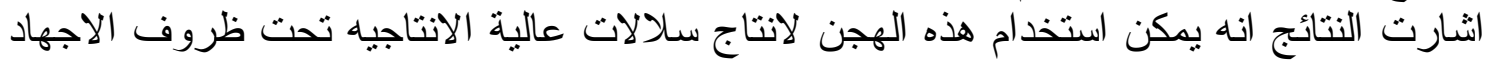

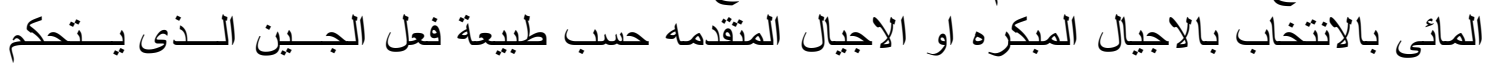

